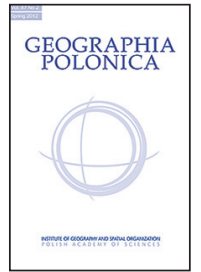

\title{
ECONOMIC USE OF THE BABIA GÓRA MASSIF AND THE ASSESSMENT OF ANTHROPOGENIC CHANGES IN THE COURSE OF THE TIMBERLINE
}

\author{
Adam Łajczak ${ }^{1}$ Tomasz Lamorski \\ ${ }^{1}$ Institute of Geography \\ Pedagogical University of Krakow \\ ${ }^{2}$ Babiogórski National Park
34-223 Zawoja 1403: Poland
}

Podchorążych 2, 30-084 Krakow: Poland

e-mail: alajczak@o2.pl

\begin{abstract}
In Poland's Babia Góra Massif (the most elevated ridge in the Western Flysch Carpathians), and in the surrounding valleys, various kinds of economic use of natural resources have been engaged in the last 600 years or more. However, the most major changes in the natural environment here have taken place under the influence of grazing and forestry. Some such economic uses already represent forms of human activity that are now history, their cessation being the prerequisite for a regeneration of vegetation that is now ongoing. One of the most visible effects of past grazing is a lowered timberline first and foremost coinciding with the more accessible southern slope of the massif. In turn, on a small part of the steep northern slope degraded by grazing, avalanches have become active, along with debris flows of earlier times, both of which also served to fragment forest. Protection of the Babia Góra Massif has brought the end to grazing referred to, and this has allowed for the progressive return of the timberline to its previous position. Overall, the work described here is based on information from the literature, unpublished studies and maps dating back over the last 400 years.
\end{abstract}

\section{Key words}

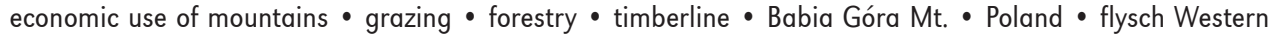
Carpathians

\section{Introduction}

Despite the obstructed accessibility, mountain massifs - even those that are highly elevated - have long been the object of economic use that has brought about changes in the environment. Visible effects of these changes include extensive deforestation of slopes, vegetation degradation in the sub-alpine belt, as well as a lowering of the timberline. Reasons cited in the literature more regularly that are deemed to have degraded the natural environment in high mountains include mining, grazing, deforestation and hiking (Midriak 1994; Mirek 1996; Motta \& Nola 2001; Boltižiar 2007; Slaymaker \& Embleton-Hamann 2009; 
Weisberg et al. 2013). An even greater number of anthropogenic factors degrading the timberline was given by Holtmeier (2009), who drew a distinction between those that had become extinct and those that were still active. In the case of the Polish Carpathians, the issue was signalled for the rather isolated mountain known as Babia Góra (Łajczak 1995), while the wider picture took account of the Tatra Mts (Mirek 1996) and Mt. Pilsko (Łajczak 2004a, 2011, 2012).

The aim of the work described here has been to reconstruct, and to organise chronologically, all of the economic/management methods made use of on the Babia Góra Massif, which is the second most elevated region in Poland and the part of the Western Flysch Carpathians reaching the greatest altitude (Fig. 1). Natural, political and social factors are seen to account for the economic development of the various methods by which the mountains in question are put to use, as for the disappearance of many of these methods over time. The main attention here is paid to the period of the last 400 years, during which the timberline has lowered along many sections as a result of human pressure. The analyzed types of human economic activity are continuous causal factors explaining changes in the course of the timberline, or reasons for a lack of change in the course thereof, and in either case the issue is of major importance in terms of both nature and the landscape.

\section{The study area}

The Babia Gora Massif is the highest flysch mountain ridge in the Western Carpathians, at a relative height of $1100 \mathrm{~m}$. It is formed as a monoclinic asymmetric ridge of length $10 \mathrm{~km}$, oriented W-E, with a steep northern slope. Its boundaries are marked by the Lipnicka and Jałowiecka Passes, between which there are two summits of the massif - Diablak (at 1725 m a.s.l.) and Cyl (at 1517 m a.s.l.), as separated by the Brona Pass (Fig. 1). The main ridge is connected to lower side ridges. The upper part of the ridge is built of Magura sandstones and the lower part by the
sub-Magura layers. The Babia Góra Massif includes the following zones, differentiated by slope inclination and their accessibility (Łajczak et al. 2014): a narrow ridge plateau, a gently inclined upper part of the southern slope, a steep upper part of the northern precipitous slope, a less-inclined middle part of the slope, a lower steep part of the northern and southern slopes, and the foot of the slopes with valleys. Extensive landslides with ridge and slope trenches are present on the moreelevated slopes of the massif, where there are also dilatation caves, niches and rock walls, as well as coluvial ramparts and tongues, accompanied by marshes, bogs and lakes.

The Babia Góra Massif, elevated to between 200 and $800 \mathrm{~m}$ above surrounding ridges, is clearly visible even from areas more than $100 \mathrm{~km}$ distant. For this reason the area has since the late Middle Ages been an object of interest as a potential place of occurrence of metal ores, a grazing area and a rich source of forest resources (Nowalnicki 1979; Siemionow 1983; Łajczak 1995). Exploitation of the natural resources of the massif was facilitated, despite the difficult terrain, by the proximity of trade routes and later colonisation including ever-more elevated areas close by (Janicki 1996).

\section{Research methods}

The main basis for the work described here was provided by the publications of Polish authors representing different fields of knowledge, these including information on various aspects to the history of economic utilisation on Babia Góra and its surroundings. Information from studies published over the last 550 years has been analyzed, with equal attention paid to older and more-contemporary sources of information. A number of littleknown publications or publications not known among geographers were included, these supplying the information necessary for changes taking place over time and within this area to be assessed (mainly in line with altitude above sea level), with respect to various kinds of economic activity engaged in the 
study area. All of the available maps from the 16 th century have been analysed with a view to changes in the areas subject to utilisation being assessed. A great deal of consideration has been given to publications of the Babiogórski National Park and the Polish Tourist Association, especially in the context of the Babia Góra Centre for Mountain Tourism operating in the 1970s and 80s (yearbook - Babia Góra Papers/Prace Babiogórskie), as well as unpublished works held at the archives of the Babiogórski National Park in Zawoja. While many of the items of literature cited are more of a popular than scientific nature, their inclusion was necessary for fuller documentation as regards the research topic addressed.

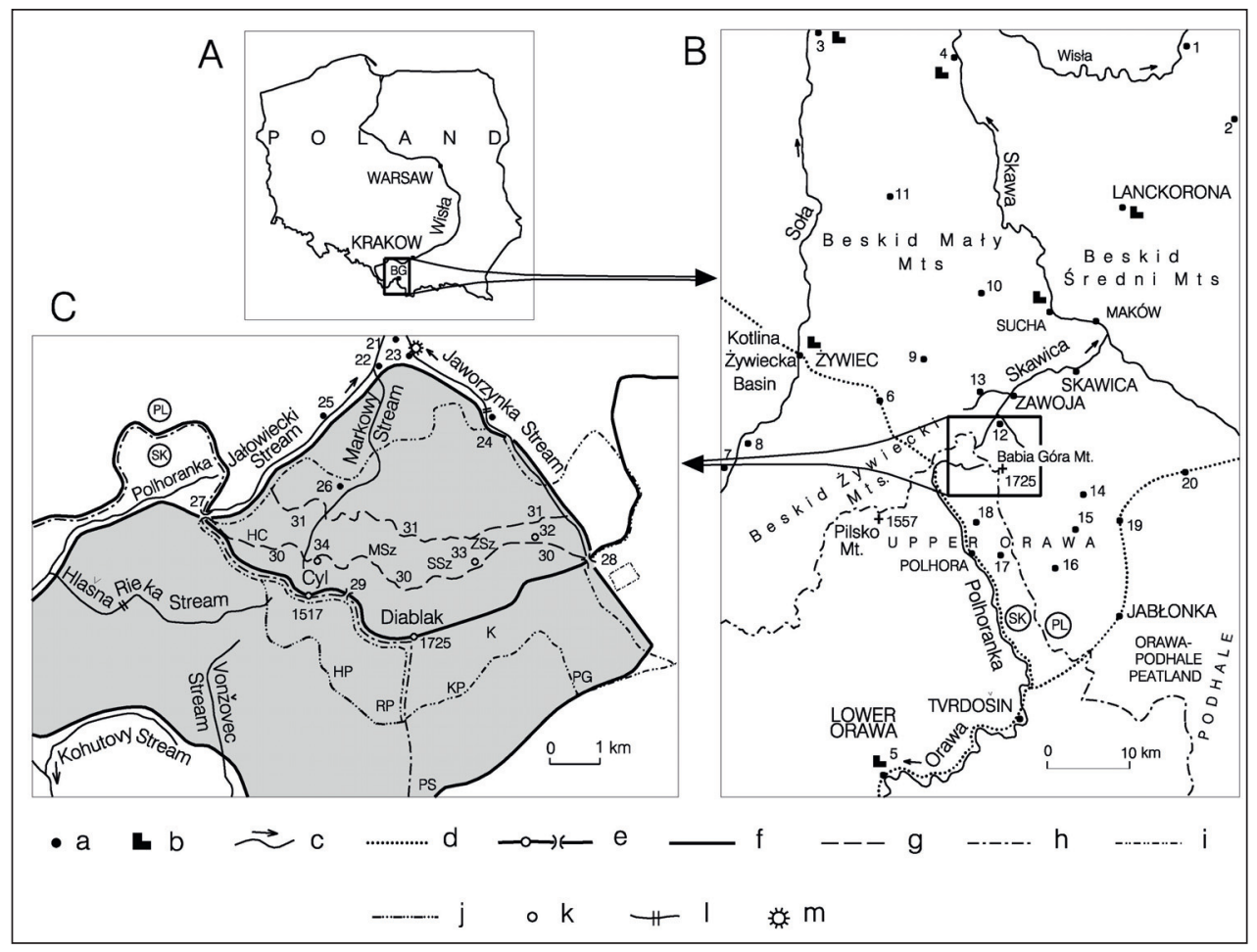

Figure 1. Location of the study area

A - location of Mount Babia Góra (BG) in Poland, B - surroundings of Babia Góra in the Western Carpathians, C - Babia Góra. a - towns and other topographic objects mentioned in the text (1 - Tyniec, 2 - Mogilany, 3 - Oświęcim, 4 - Zator, 5 - the Orava Castle, 6 - Jeleśnia, 7 - Kamesznica, 8 - Węgierska Górka, 9 - Hucisko, 10 - Targoszów, 11 - Andrychów, 12 - Górna Zawoja, 13 - Zawoja-Wełcza, 14 - Zubrzyca Górna, 15 - Lipnica Mała, 16 - Lipnica Wielka, 17 - Rabčice, 18 - Slaná Voda, 19 - Podwilk, 20 - Spytkowice, 21 - Zawoja-Widły, 22 - Zawoja-Składy, 23 - Zawoja-Wilczna, 24 - Zawoja-Policzne, 25 - Zawoja-Czatoża, 26 - Markowe Rówieńki), b - castles, c - streams and rivers, d - historical trade routes, e - main ridge, summits, passes (27 - the Jałowiecka Pass, 28 - the Lipnicka Pass, 29 - the Brona Pass), f - limits of the Babia Góra massif, g - the Płajs (30 - upper Płaj, 31 - lower Płaj), h - state border, $\mathrm{i}$ - boundary of Babiogórski National Park, j - border of the Nature Reserve in the Slovak part of the massif, k - landslide lakes (32 - Mokry Stawek lake, 33 - Stawek pod Kłoda lake, 34 - Markowy Stawek lake), I - installations for floating timber (klauza and tajch), m - Bajerska Maszyna. The largest areas grazed by sheep and/or oxen (mid-forest clearings, dwarf pine scrub): HC - the Hala Czarnego clearing, MSz - Markowe Szczawiny glade, SSz - Sulowe Szczawiny glade, ZSz - Żarnowskie Szczawiny glade, HP - Hustianska Polana clearing, RP - Rabčicka Polana glade, KP - Kralowa Polana clearing, K - Kuhynia, PG - Polana Gubernasówka clearing, PS - Polana Stańcowa clearing 


\section{Results}

\section{Means of economic utilisation of the Babia Góra Massif and its surroundings}

Within the limits of the Babia Góra Massif, at its foot and in the surrounding area, the following means by which land might be made economic use of have developed from the time of onset of permanent settlement in the area:

A - settlement and agriculture (deforestation of land, development of rural housing, extensions in the area of agricultural land, the construction of castles and towns),

$B$ - the extension of paths and roads beyond developed areas,

C - the exploration and exploitation of flysch rocks treated as 'ore' for iron and cooperating forges,

$D$ - the search for plants serving medicinal purposes,

E - deforestation and the cutting-out of dwarf mountain pine scrub to create grazing areas and the founding of forest clearings,

F - grazing, mountain farming, meadow management,

$G$ - forestry and timber management (the deforestation and reafforestation of deforested areas, the use of wood in various fields of human activity, including charcoal production meeting the needs of the steel industry),

$\mathrm{H}$ - transport of wood by water and the construction of installations serving transport by water,

I - the construction of health facilities and tourist development,

$\mathrm{J}$ - skiing.

The listed forms of human activity should also be extended to include legal measures protecting nature in the area $(\mathrm{K})$. The indicator of changes in landscape in the study area due to the combined effect of these types of economic activity is the ongoing reduction in area of forests and dwarf mountain pine scrub $(L)$, as well as changes in the species composition of forests. In some areas of the massif, this has led to a lowering of the timberline, which is now returning to its previous altitude, however.

\section{Evolution in the types of local economy}

The history of the economic use of Babia Góra and its surroundings can be related to 7 distinguished periods, varying in line with the seriousness and consequences of all or some of the forms of economic activity taking place. The durations of the different activities differ, as each appeared at a different stage of the area's development. Likewise, the gradual or rapid abandonment of these forms of activity took place at different times.

Period I (to the 11th century): The earliest known traces of a human presence on the Orava foot of Babia Góra in Lipnica Wielka have been dated to 11,000 years BP and represent the hunter-gatherer economy. The area also supports traces of people from the Neolithic period and, at numerous places along the Orava Valley, people of the Bronze and Iron Ages, with a permanent population of the southern foreland of Babia Góra indicated in the fourth century (Rydlewski \& ValdeNowak 1984). On the west side of Babia Góra - in the Soła Valley and Żywiec Basin, it has proved possible to find output of the so-called Lusatian culture, as well as products making clear that the beginning of our era saw the Roman Empire trade with people inhabiting Polish lands (Łajczak 2011). One Roman trade route ran north through the valley of the Orava and the Spytkowicka Pass (Siemionow 1983).

However, this part of the Carpathians was later subject to depopulation, only to be recolonised in association with the influx of the Slavs in the 6 th and 7 th centuries. The first built Slavic settlement in the Lower Orava region in turn dates from the 8th-9th centuries. In the latter century, the environs of Babia Góra were at the external frontiers of Greater Moravia, later coming within the state of the Vistulans, though not coming under settlement at this time. Both states created in the 10th century, Poland and Hungary had a common border in this part of the Carpathians, along the main ridge of the Beskid Żywiecki range. Access to Babia Góra was hindered by the Carpathian Forest or Nigra Silva, which 
extended into the surroundings of Tyniec and Mogilany near Krakow, as well as into the northern part of Orava on the south side of the massif. Access from the Podhale region was in turn greatly obstructed by the presence of extensive peat bogs (Siemionow 1983).

Period II (12th-15th centuries): The next phase to settlement around Babia Góra began in the 12th century, and was associated with the agricultural colonisation of lower sections of the Skawa and the Soła Valleys, the Żywiec Basin and the valleys of the Váh and lower Orava. The population inhabiting the distant foreground of Babia Góra on its northern side came from the area of the Vistula Valley in the vicinity of Krakow, Oświęcim and Zator. By the 15th century, settlement extended into the central part of the Skawa Valley, by this time being just $25 \mathrm{~km}$ from Babia Góra, while Slovak settlement advancing up the Orava Valley was by the late 12th and early 13th centuries reaching the surroundings of Tvrdošín (Broda 1963). In turn, in the 13th and 14th centuries, settlement was related to the distribution of towns and castles some 25-50 km distant from Babia Góra, on its northern and southern sides (Nowalnicki 1979; Siemionow 1983). The thirteenth century brought construction of Orava Castle as the administrative center of the Orava region, while in the 14th century the castle in Lanckorona was constructed on the Polish side. In 1378 the settlement of Maków on the Skawa was established, this reducing by half the distance between Babia Góra and settlement at Lanckorona castle. The founding of these villages was intended to support the movement of freight along trade routes leading from Krakow, Wieliczka and Bochnia through the valleys of Raba and Skawa and onwards - close to Babia Góra - via the Upper Orava Valley into Hungary. Another trade route ran from Silesia through Żywiec and Jeleśnia, and then near to Babia Góra via Polhora and the Orava Valley to the south. In the 14th and 15th centuries in turn, these trade routes were used to transport copper from Hungary to Poland, as well as salt, zinc, lead and silver into Hungary.
The economic development of Poland and Hungary increased the demand for metal ores, which were also being sought on the Babia Góra Massif. The information given by Długosz (1468) on the abundance of herbs here points to the penetration of the massif by herbalists, at least from the first half of the fifteenth century onwards, i.e. even prior to the introduction of grazing into the area. At this point the area occupied by the Silva Nigra extended for about $50 \mathrm{~km}$ on either side of Babia Góra. It is possible that ores were already being searched for at this time, even in the surroundings of the summit of the massif, though the first information on this topic derives from the early 17th century (Nowalnicki 1979; Siemionow 1983). In the southern foothills of Babia Góra, the first prospecting for gold, silver, lead and copper took place at the beginning of the 16th century. That work, carried out by the Special Hungarian Commission for Salt Resources, was associated with exploration for salt at the already known Slaná Voda source near Polhora. The activities did not produce the expected results, but it was on the basis of them that a 1550 map of the Upper Orava region was developed, indicating the presence of saline springs (Ruciński 1976; Nowalnicki 1979). The incentive for such a search might have been the mining work being done in the vicinity of the town of Żywiec, in which small amounts of silver were mined in the 15th and 16th centuries (Łajczak 2011) as well as the steel industry which had been started with in the 15 th century on the northern side of Babia Góra, where the village of Hucisko was settled at a site from which sphaerosiderites were mined and clay ores processed by the oldest furnaces in the Beskidy Mountains (Jost 2004).

Period III (16th-18th centuries): Significant changes in the nature of Babia Góra Mt. and its immediate vicinity occurred as a result of the area's settlement, in the 16th and 17th centuries, of the Vlachs ethnic group which had migrated to the Western Carpathians in the 14th and 15th centuries, from the Balkans. The Vlachs occupied uninhabited or sparsely-populated mountain valleys, in the vicinity of Babia Góra, the Skawica Valley and 
other valleys in the Upper Orava region. They developed larger-scale grazing, which had not been known in the area hitherto. In the second half of the 16th century, villages under the Vlach law were settled in valleys on both sides of Babia Góra, while areas located closer to the foot of the massif were brought within the extending settlement network in the first half of the 17th century. In the 18th century, in turn, a next wave of settlement ensured that areas populated now also included valleys in the foothills of Babia Góra. It was then that a number of settlements forming the current Górna Zawoja village came into existence, while in the southern foothills of the massif, the most-elevated settlements of Zubrzyca Górna, Lipnica Mała, Lipnica Wielka, Rabčice and Polhora were also founded (Broda 1963; Janicki 1996).

The development of settlement was associated - in the $250+$ years up to the late 18th and early 19th centuries - with deforestation of valleys on the northern and southern sides of Babia Góra, as well as parts of the foot of the massif. The area occupied by the forests formerly forming part of the Nigra Silva shrank from 50 to $10 \mathrm{~km}$ wide, coming to include only the main ridge of Babia Góra and most areas at its foot. Along the bottoms of local valleys, linear-settlement villages were created, while other deforested areas came to be taken by agricultural fields ascending to $800 \mathrm{~m}$ a.s.l. on the slopes. At the turn of the 18th and 19th centuries the agro-forestry border was created at the foot of Babia Góra, its course being shown on the maps by Liesganig et al. (1790) and de Lipszky (1806). This border was later changed only little, despite the increasing forestry.

Grazing required the creation of forest clearings and the planning of routes that livestock animals might take. On the southern slope of Babia Góra, clearings began to take shape at the beginning of the 17th century (the oldest information on this being from 1615 - Jostowa 1986). The equivalent activity on the northern slope characterised the 18th century. Grazing, in addition to clearing, also extended to adjacent parts of the forest and to the scrub of dwarf mountain pine and the alpine grasslands at still-higher altitudes, with grass there being cut to provide animal feed. The extents of the largest clearings on the northern slope of Babia Góra are already being shown on the map by Mieg (1779-1782), though their extent on the slopes is presented in detail on the map by Kummerer Ritter von Kummersberg (1855), as well as on the map in the paper by Zapałowicz (1880), which refers to the whole of Babia Góra. On the gentle southern slope of the massif large clearings accommodating grazing sheep were created, at different altitudes, with these stretching from the foot of the slope to the timberline. The clearings at the highest altitudes bordered with the zone of dwarf mountain pine scrub, with mountain grasslands being grazed by Pinzgauer oxen as early as in the 17th century (Jostowa 1983). According to the cited author, the southern slope of Babia Góra was being grazed in areas above the timberline known as the Wielka Polana, U Paleniska, Kotarnia Młaka, Suche Smreki and Kuhynia. In the 17th century, the Gubernasówka and Stańcowa clearings were created at low altitude, while in the 18th century it was the Kralowa Clearing (900-1400 m a.s.I.) that was created. On the southern slope of the massif there were also extensive clearings that are currently on the Slovak side, as mentioned by Zapałowicz (1880). On the southern slope, shepherds were forbidden to cut trees at the edges of the clearings, so they used dwarf mountain pine as fuel in their shelters (Jostowa 1983). The effect of this was the generation of a sparser scrub of dwarf mountain pine, or locally even its total elimination. The effects of the degradation of dwarf mountain pine scrub are still to be made out on the mountain slope (Piasecki 1999; Holeksa \& Szwagrzyk 2005). Grazing on the less-accessible northern slope of Babia Góra extended over a more limited area of land. Clearings were created on the less inclined part of the slope, below the great rock slump. This means that they were not present at altitudes in excess of $1275 \mathrm{~m}$ a.s.I. As shown on maps (Kummerer Ritter von Kummersberg 1855; Zapałowicz 1880), there 
were 13 grazed clearings on the slope in the 19th century, with reference to their sizes making it clear that most had taken shape during the 18th century. This can be confirmed by a statement in the work by Chmielowski (1745-1756), on the whole Babia Góra Massif: "[Babia Góra] is covered with sheep".

The forests on the northern slope of Babia Góra Mt. were, from the 15th century through to 1772 , under the successive ownership of the Komorowski family, the Swedish Vasa Dynasty reigning in Poland and the Wielopolski family. At that time, the forests of the southern slope of the massif belonged to the owners of Orava Castle. As grazing developed, areas beyond those used for sheep and oxen saw small-scale disorganised exploitation of forests carried out in low-lying areas of the massif only (Dzięciołowski 1963; Fabijanowski \& Gadek 1983). At that time, charcoal and tar were being produced from beech wood in the valleys at the foot of the massif. Babia Góra's forests were still, in most parts, accounted for by the Carpathian primeval forest (a remnant of the vast Silva Nigra) with the lower montane zone supporting old-growth fir and beech and sycamore or just fir - hence the Latin name for this forest (Kawecki 1936). The initial status was represented, almost across the area by montane coniferous forests. Scrub of dwarf mountain pine was already degraded, especially over a large area on the southern slope of the massif.

Settlements developing around Babia Góra combined with grazing on the slopes of the massif to facilitate its further penetration by herbalists, as evidenced by the writings from Marcin of Urzędów (1595), Syreński (1613), Rzączyński (1721) and Chmielowski (1745-1756). Information given by the last of these authors, reading that: "Babia Góra Mt. has herbs and pharmaceutical powders" also presumably indicates an interest in the colloidal sulphur present in sulphide springs at the southern foot of the massif. The white-gray sludge in these springs also caught the eye of Duńczewski (1755-1769), who wrote: "(..) white and light chalk - the milk of which helps to heal various diseases (...)". From the 16th century onwards, the Slaná Voda springs near the village of Polhora were used by local people for medicinal and economic purposes, including via the obtainment of salt for consumption. In 1755 the springs were again made subject to test-digging for a deposit of salt, though limited amounts found in the ground there ensured that this activity was soon brought to a halt (Palenik 1980; Trnka 2005). The search for ores was ongoing at that time, however. The '1643' engraved on the rock wall of the gully below the culmination of Babia Góra (Midowicz 1992) documents the penetration of the mountain's most inaccessible slopes almost 400 years ago. In turn, the oldest known characters carved in the rock crevices at the Orava foot of Babia Góra date back to the 18th century (Nowalnicki 1982). Information about mine prospecting conducted in the 17th century throughout the Babia Góra area is included in the papers of Hrosieński (1637) and Haur (1660). Observations of the lakes then called Oculus Mare and considered deep, and entries into the slots in the deep rocky landslide crevices, both dating back to the 18th century, point to an interest in the shaping and building of this massif, in some cases possibly in the context of the search for metal ores (Rzączyński 1721, 1742; Łubieński 1741; Chmielowski 1745-1756; Duńczewski 1755-1769; Ładowski 1783). Exploration for metal ores and salt on Babia Góra and in the surrounding area should both be linked with the creation (in the 18th century or even earlier) of roads through the passes in the massif that were to serve as alternatives to those passing through Spytkowice and Podwilk and through Jeleśnia and Polhora, these being the routes that exported lead from Poland to Hungary (Wyrozumska 1977; Nowalnicki 1979). The course of these roads was first shown on the map by Liesganig et al. (1790), as well as on the map in the paper by Zapałowicz (1880). The paving of roads close to the Babia Góra Massif might therefore indicate the hopes once held out for successful prospecting and exploitation of metal ores and salt. In the analysed era, Babia Góra does seem to resemble the 
Tatra Mts. in being treated as promising from the point of view of mining. The scale of interest in it can be evidenced by such maps by Porębski (1563), Orteliusz (1573), Merkator (1585) and by Rizzi Zannoni (1772) - in each of which the massif under study was marked in print of similar size to that used to denote the Tatras, or even larger.

Period IV (the turn of the 18th and 19th centuries): In 1772 the southern part of the Polish Kingdom was incorporated into the Austrian Monarchy as Galicia - a province which included the northern slope of Babia Góra, together with its foothills. As early as in 1526, the northern part of the Kingdom of Hungary had come under Austrian control, this therefore including the mountain's southern slope and foothills. All of Hungary became Austrian in 1699. The forests on the northern slope of Babia Góra were thus taken on by the Austrian government, the loss being that of the last Polish owners - the Wielopolski family. Austria thus took advantage of what resources were available up until 1839. It was indeed during this period that logging of the foothills here began. Though existing alongside grazed meadows, the more-elevated forests on the slopes of the massif had been of a relatively natural character (Kawecki 1936; Dzięciołowski 1963; Fabijanowski \& Gądek 1983). The logs cut from them were moved down slopes and then floated via streams and rivers. In the foothills of Babia Góra wood was still being used in the production of charcoal, tar and various tools (Zejszner 1848). At the beginning of the 19th century, the villages in the Orava region making use of clearings on the southern slope of Babia Góra for grazing were required to provide logs to the Orava Castle, and to this end these floated down the River Polhoranka (Jostowa 1983). Large-scale timber floating on the river can be seen on the map by Liesganig et al. (1790). This map marks timber stores on the banks of the said river. Siemionow (1983) has it that, in 1807, Mr J. Schultes (an Austrian and the first person to speak up for the protection of Babia Góra) drew attention to the fast rate at which forests in the lower parts of the massif were being cut, as well as to the rafting of the logs obtained down the Skawica. Comments on this subject are present in the German encyclopedia Allgemeine Encyclopedias der Wissenschatt $u$. Künste published in the years 1818-1882, as well as in a description of the lands of the Austrian monarchy of 1843 , in which it is stated that "...) streams [on Babia Góra], at times of high water are used for floating timber" (Polak 1980).

The advanced development of grazing in the analysed period was highlighted by Staszic (1815), who investigated Babia Góra and its surroundings in July 1804; as well as by Zejszner (1848), who stated that - during his trip of 1830 along the main ridge from the west, before reaching the summit of the massif - "We were moving on the immense spaces overgrown with grass, on which numerous herds were grazing". The comment can be applied to grazing land around Cyl and the Brona Pass, where sheep and oxen were indeed grazed. However, metal ores were still also being prospected for on Babia Góra at this time (Siemionow 1983).

Period V (1839-1924): 1839 brought a start to the next stage of economic activity on Babia Góra. A fast-growing iron industry on the northern side of the range led to decrease in primary forest cover on the northern slope, this meaning the gradual disappearance of the Silva Nigra from the foot of the slope. At the same time, the area of old growth on the southern slope of Babia Góra was also declining.

In 1839, the Austrian government sold the Maków Estate, including the forests on the northern slope of Babia Góra, to Count Philip Louis de Saint Genois d'Anneacourt, the land later passing to his son, Count Maurice de Saint Genois. The latter, in his turn, made an 1878 sale of the Maków Estate (with the village of Zawoja) to the Habsburg Archduke Albrecht, owner of the Żywiec Estate (Janicki 1996). This sparked a rapid decrease in the extent of old-growth forest on Babia Góra, a phenomenon that assumed peak intensity in the second and third decades of the 20th century (Dzięciołowski 1963). 
While the traditional iron industry on the northern side of Babia Góra dates back to the 15th century (at the village of Hucisko), the Skawica and further Skawa Valleys only became home to foundries and forges in the first half of the 19th century (Jost 2004). The thermal energy for the blast furnaces and more primitive furnace technologies alike came from charcoal that was made from the partial combustion of beech. Wood from the trees growing at higher altitudes was more valued in this production - hence the almost-complete removal of forests from the lower montane zone of Babia Góra in the analysed period (Dzięciołowski 1963; Fabijanowski \& Gaqdek 1983). The sources of mechanical energy were in turn the local watercourses, which are characterised by a steep gradient at the foot of Babia Góra and have adequate discharges even in periods of low-water (Łajczak 2004b). The raw-material base for the region's iron foundries were in turn the flysch formations, supplying up to $15-20 \%$ of the iron mined in 30 mines of the Beskid Maty and Beskid Średni Mountain ranges, above all in the areas around Targoszów and Krzeszów. Limestone coming from the Andrychów area was used as flux (Janicki 1996; Jost 2004).

From among the 35 metallurgical plants operating in the 1840s (the period of peak development of this industry in the part of the Carpathians within Galicia), 9 were in operation on the northern and western sides of Babia Góra, within a $40 \mathrm{~km}$ range, and 3 within a $25 \mathrm{~km}$ range (at Zawoja, Maków and Sucha). Communications with these were mediated via the rivers Skawica and Skawa. At Maków and Sucha it was iron smelting that was engaged in, while at Zawoja, pig iron imported from nearby iron foundries was processed further (Jost 2004). It was the Sucha Metallurgical Works in Galicia that were in operation for longest, between 1828 and 1886 . The Sucha Plant gained its first blast furnace in 1836, while a second was installed in 1846 . Another facility of this type, the Maków iron foundry owned by the proprietor of Estate of the same name, Count Philip Louis de Saint Genois d'Anneacourt, was built in the years
1845-1847 and was active until 1863. Together, the two formed a complex of metallurgical installations, comprising 3 blast furnaces, 10 other metallurgical installations and a rolling mill. In 1842, the Mining Authority in Wieliczka granted a concession for the construction of an iron furnace and ironworks in the centre of Zawoja which was to supply the iron foundry in Maków (Kawecki 1939). The collapse of all of the plants in the second half of the nineteenth century was due to competition from cheaper iron imported from Silesia, via the railway lines built in that period (Janicki 1996; Jost 2004).

The development of the iron industry was related to further prospecting by miners from Bochnia and Wieliczka in the flysch rock of Babia Góra characterised by a high content of the metal (Midowicz 1930, 1974, 1992; Nowalnicki 1979). Encouragement for this work came with 19th-century extraction from flysch rocks in the area of Jeleśnia and Kamesznica, with a view to the iron foundry in Węgierska Górka being supplied (Drobisz 1985). However, the search for metal ores on Babia Góra failed, on account of the low contents of iron in the massif's rocks. Research carried out in the 1950s made it clear that the $\mathrm{Fe}_{2} \mathrm{O}_{3}$ content here reaches only $6.4 \%$ by weight in the case of the layers of mudstone in the hieroglyphic layers forming the lower part of Babia Góra, as well as the sandstones in the Magura claystones forming the more-elevated part of the massif(Wieser et al. 1959-1960). The evidence for the mining activity continued with in various parts of Babia Góra up to the beginning of the second half of the 19th century is provided by wooden support structures surviving even through to the 1920s, in the case of certain crevices in some parts of the ridge (Stieber 1924; Midowicz 1974). These are augmented by still-visible signs engraved on the rocky walls of certain slopes and ridge trenches, with '1865' being the earliest known date (Midowicz 1930, 1974, 1992; Nowalnicki \& Łajczak 1981; Nowalnicki 1982). Mining work also accounts for the digging of a small pit on the northern slope at an altitude of 1075 m a.s.l. on Babia Góra, 
this being described in the literature as a miniature and relatively deep lake called Stawek pod Kłoda (Sosnowski 1923; Midowicz 1974; Nowalnicki 1980).

After 1878, Albrecht Habsburg assigned the forests acquired from Żywiec on the northern slope of Babia Góra to prestige hunting. To this end, in 1883 the track known as the Upper Koniopłaj (Upper Płaj) was created, this traversing the slope in an E-W direction from Zawoja-Czatoża through the Markowe Szczawiny glade to Zawoja-Policzne (Midowicz 1985). On the section between the Hala Czarnego clearing and Mokry Stawek lake, the Upper Płaj runs at altitudes between 1100, 1180 and $1050 \mathrm{~m}$ a.s.l. (Figs. 1, 2). At the western and eastern ends of the Płaj hunting accommodation was built - near the Markowy Staw and Stawek pod Kłoda lakes. The Płaj was actually a development of a grazing path established pre-1836, which connected the most-elevated clearings on the northern slope of Babia Góra, i.e. the Sulowe Szczawiny, Żarnowieckie Szczawiny and Markowe Szczawiny glades, and the Hala Czarnego clearing, with roads running through the Lipnicka and Jałowiecka Passes (Nowalnicki 1979). A few years later, a range of altitudes of 750-950 $\mathrm{m}$ a.s.I. was selected for the development of a Lower Płaj, also running $W-E$, which connects with the marginal parts of the Upper Płaj and via a long middle section running at an altitude of 950 m a.s.l. (Fig. 1). It was the locations of the Płajs that for some time determined the upper limits of the large-scale felling of forest on the northern slope of Babia Góra.

Deforestation on that northern slope to serve the production of charcoal for the iron foundry in Maków was justified, from the 1840s onwards, in terms of the "excess [!] of wood in the forests of Mt. Babia Góra" (Dzięciołowski 1963). The thought was a guide for those who decided on the fate of the forests here, and should be regarded as the cause of their liquidation over almost their entire former area of occurrence, this then being the last relic of the previously very extensive Silva Nigra of the Western Carpathians. Paradoxically, the closure of the iron foundries in Maków and Sucha, was even followed by accelerated deforestation of Babia Góra, due to an increased demand for wood as a result of a rapidly increasing population in the vicinity of the massif, and the construction of the Sucha Beskidzka - Chabówka railway line, which ensured markets for the sale of wood rather further afield. For example, the number of inhabitants of the village of Zawoja increased from 1000 people in 1865 to almost 5000 in 1900. The village was overpopulated at this point, and supplies of oats and potatoes were not always assured. The low incomes of the population from agriculture and grazing ensured that the handling of transported wood became increasingly popular work, along with carpentry and the manufacture of various pieces of equipment from wood, with a view to the output being sold over a large area of western Galicia (Schneider 1871; Janicki 1996). Exploitation of local forests required accurate mapping of the area, and this was prepared in 1844, on the basis of the triangulation work of Carl Kummerer Ritter von Kummersberg. The map in question in turn served as a basis for the development of forests utilization plans in respect of Babia Góra's northern slope. In line with these plans, forests were exploited to the point where they had been felled entirely by 1924. No young trees were cut, however, so notwithstanding afforestation with spruce and a small amount of beech, fir and sycamore, the original forest species composition was maintained over large areas of the lower forest montane - marked contrast with the many spruce monocultures generated at that time (BgPN Archives). Other areas of the zone did indeed come to be dominated by spruce alone (Dzięciołowski 1963).

On the northern slope of Babia Góra, largescale felling of forest took place from 1840 onwards, commencing with the foot of the massif, which crossed the Lower Płaj in only three areas up to the early twentieth century. Although the next owner of the Zawoja Estate, Stefan Karl Habsburg, decided that further felling of forest on the slope should not cross the Płaj, the deforestation taking place in 1918-1919 did indeed extend up 
A

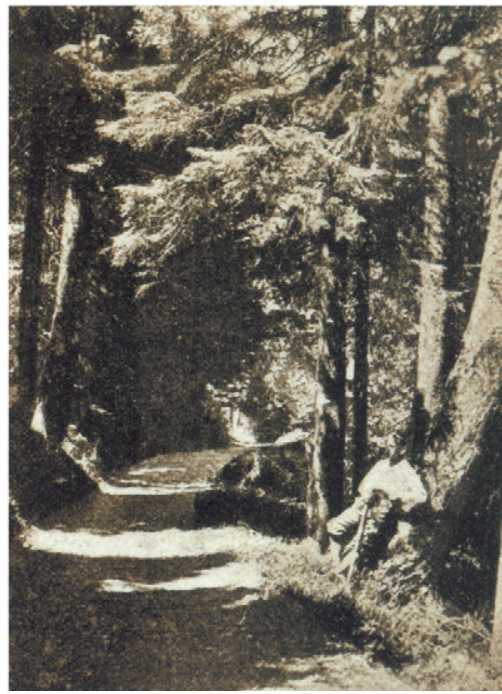

B

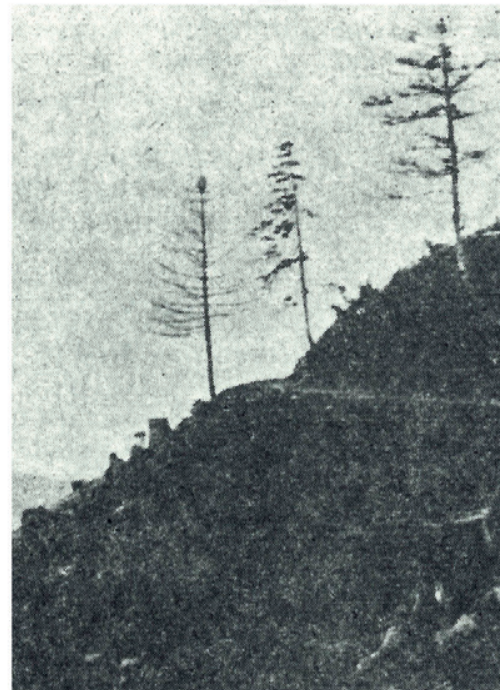

Figure 2. A - old-growth spruce forest of the upper Płaj around 1900, B - forest cut on both sides of the track as of 1925

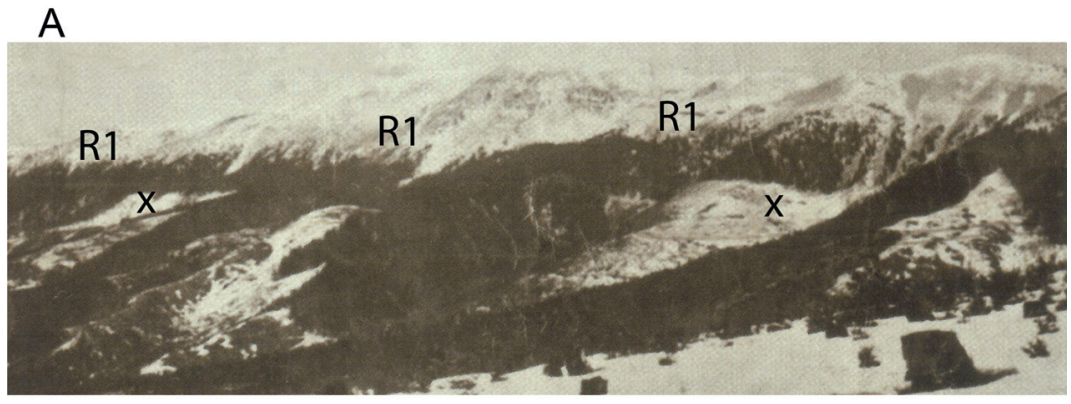

B

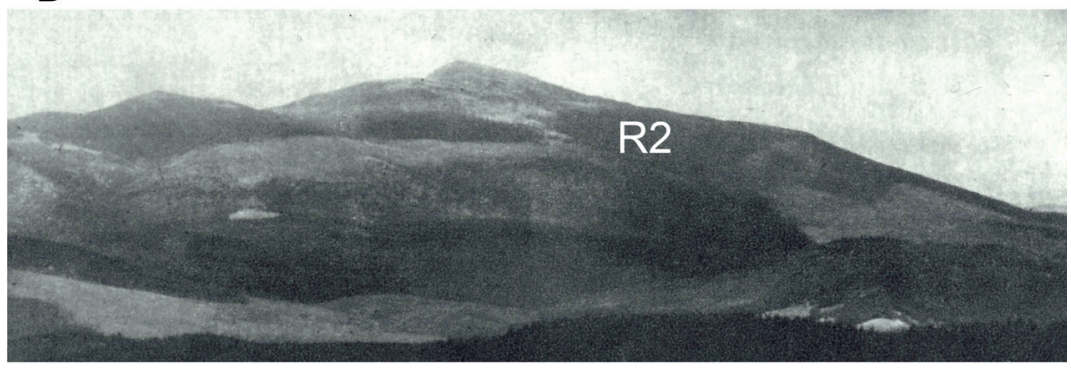

Figure 3. A - deforestation of the northern slope of Babia Góra as of 1926 reaching the upper Płaj, and crossing this path in two locations (marked with an X), B - deforestation of the western part of Babia Góra's southern slope around 1925, reaching the timberline in certain localities. Nature Reserves: R1 - the "Babia Góra" NR created in 1933 and taking in most of the upper montane forest zone above the upper Płaj and the slope located above, R2 - the "Kotlina pod Babią Góra" NR established in 1926 
slopes to reach the lower range of - or even to penetrate - the upper montane forest zone, with the upper Płaj crossed at two sections (BgPN Archives; Midowicz 1985). There, felling of trees at altitudes of $1250 \mathrm{~m}$ a.s.l. took place, which is to say that a zone maximally $50 \mathrm{~m}$ wide was all that separated these from the timberline on the line of gullies (Fig. 3A). Only five parts of the slope were covered with large areas of the original lower montane forest through to 1924, though most of the upper montane forest was saved from being cut. Of similar scale was the felling of forest on the southern slope of Babia Góra (Fig. 3B).

It is from the 1840-1924 period that secondary forest stands present on Babia Góra date - the ages differing from place to place depending on where clear-felling took place, albeit in such a way that each part of the slope has forest of similar ages overall (BgPN Archives).

In the second half of the 19th century and early 20th century, the aftermath of the closures of the Maków and Sucha foundries coincided with intensified floating of logs along the large streams of the massif's northern side (the Jaworzynka, Markowy Potok and Jałowiecki), as well as along the Skawica river; and on the southern side of the massif along the Hlásná Rieka and Vonžovec streams and the river Polhoranka. The recipients of the wood on the transport route were charcoalburners on the northern side of Babia Góra located on the Markowe Rówieńki, in ZawojaWidły and in the centre of Zawoja. Logs were floated loose along the Skawica, with rafts built along the banks of the Skawa being used to transport further goods. The large-scale floating of wood was easier due to installations constructed in the mid-19th century, comprising dams with the wooden structure of a splash gate (called a klauza) used to regulate the flow of water from a small reservoir called a 'tajch'. The fast flow of water from each 'tajch' allowed for transport of logs where the depth of water in a stream channel was not otherwise sufficient. The 'klauzas' on the northern side of Babia Góra were built at Zawoja-Policzne on the Jaworzynka stream, at Zawoja-Wełcza on the Wełczówka stream, and on the southern side of the massif on the upper Polhoranka river and three of its tributaries (Midowicz 1992; Mazurek 2008). The distribution of the 'tajch' reservoirs at the end of the 1870s is shown on the map in the paper by Zapałowicz (1880) and, in subsequent years, on the KMI map (1915). At the confluence of the Jałowiecki and Markowy streams, at the beginning of the twentieth century, there was timber storage at the place still called Zawoja-Składy (Midowicz 1992). The recipients of the floated logs were the village sawmills of Zawoja, mostly located at ZawojaWilczna on the Jaworzynka stream, at a place which is still called Bajerska Maszyna (Janicki 1995).

In the period analyzed, there was an increase in the numbers of sheep and oxen grazing in forest and on mountain dwarf pine, as well as on clearings, though this trend did not continue after 1920. By that time, partial or total reforestation of the lower clearings on the southern slope of Babia Góra Mt. was already in progress. The effect of a further increase in the population of the foothills of the massif was the conversion of meadows into arable land (Zapałowicz 1880; Walas 1933; Kostuch 1963; Jostowa 1983). The highest intensity of grazing in the area characterised the first two decades of the 20th century. While in the second half of the 19th century sheep and oxen were grazing on 22 clearings on both slopes of the massif (Zapałowicz 1880), in the 1920s grazing was present on just 7 clearings on the southern slope and 6 on the northern (Ralski 1931; Walas 1933; Kostuch 1963). The grazing of greatest intensity at the beginning of the 20th century was that taking place on the southern slope of Babia Góra in the zone of dwarf mountain pine scrub and on the uppermost forest clearings, this being indicated by the greater later extent of the Hustianska, Rabčicka and Kralowa glades, as compared with their statuses revealed on the Zapałowicz map (of 1880). Following the cessation of grazing, these clearings remained open in the 1960s - in the direction of the higher dwarf mountain pine zone, with 
the result that the course of the timberline was lowered locally (Czajka \& Kaczka 2014).

It was in the second half of the 19th century and in the early 20th century that infrastructure for tourism and recreation began to develop on Babia Góra (Łajczak et al. 2015). Analysis of the Slaná Voda springs (Trnka 2005; Kuriakova et al. 2007) carried out at the beginning of the 19th century resulted in greater interest in these objects and their exploitation. The overall mineralisation of the springs was found to be of $150 \mathrm{~g} \cdot \mathrm{dm}^{-3}$, while the temperatures were $33-41^{\circ} \mathrm{C}$. The Slaná Voda springs were distinguished by high contents of the salts of iodine, bromine and boric acid, though they were found to be of low efficiency. In 1863, a spa with baths was built here nonetheless, though the buildings were burnt out in 1918. Today, the sources concerned are plugged, and enclosed within a well with a pump (Palenik 1980; Trnka 2005). At the beginning of the 20th century an idea to transform Zawoja into a climate resort began to take shape, this being accounted for by reference to the favourable microclimate at the northern foot of Babia Góra (Midowicz 1992). At that time the more-elevated areas of the massif, including the area around the summit, began to be made accessible to tourists through the building of hostels at altitudes of 1616 m a.s.l. (in the years 1904-1905) and $1180 \mathrm{~m}$ a.s.l. (in 1906), as well as the delineation of trails. Dwarf pine growing around the hostel at the peak of the massif began to be cut for fuel.

Period VI (1924-1954): Post-1918 the border between Poland and Czechoslovakia was delimited, this making partial reference to the old Polish-Hungarian state border. The line was agreed upon by the parties in 1924 . From that moment, a gradual change in the use made of the mountain range began, this signaling an end to utilisation of upper parts of the forests, the elimination of grazing and the protection of ever-greater areas of $\mathrm{Ba}$ bia Góra. During this period both the floating of timber and charcoal production came to an end, though the development of hiking began to intensify, on the basis of operations at the two hostels and an increasingly dense network of marked trails. In the 1930s, Zawoja acquired the status of 'climate station' (i.e. a holiday health resort) with the right to tax accordingly (Leszczycki 1939).

The starting point for changes in the management of forests on the northern slope of Babia Góra was their 1924 transfer by the Habsburgs of Żywiec to the Polish Academy of Arts and Sciences. The forests transferred were primarily secondary stands aged between $0-20$ and $60-80$ years, as well as small areas with old forest in the lower montane forest zone. The old growth forest in the upper montane forest zone had been preserved in a near-natural state over almost the entire area (Fig. 3A). Similar was the age structure of forests on the southern slope of the massif, the eastern part of which belonged to Poland from that time and the western part to Slovakia (up to 1992 to Czechoslovakia, Fig. 3B). On the northern slope of Babia Góra, the remains of old growth forest in the lower montane forest zone and some parts of the upper montane forest zone were still subject to economic use with partial felling, while monoculture spruce forests were clear-felled. Deforested areas were reafforested with local spruce, with beech and fir saplings from natural regeneration preserved (BgPN Archives). After the felling taking place in the second half of the 1920s, most of the preserved old trees of the lower montane forest on the northern slope of Babia Góra were made subject to successful efforts to refrain from further cutting (Midowicz 1985). As of 1930, the limits of large-scale felling of forest extended for a long stretch along the Upper Płaj, crossing the line in two places. It was only within four small fragments of the slope below the Płaj that old-growth forest mainly of the lower montane forest zone gained protection. On the southern slope of Babia Góra, large-scale felling of forest extended to an altitude of $1250 \mathrm{~m}$ a.s.l., as well as reaching the timberline locally (BgPN Archives).

However, the late 1920s and early 1930 s brought approval for a first founding of $\mathrm{Na}$ ture Reserves on Babia Góra, with these 
extending over the upper montane forest zone with most of the area in the dwarf mountain pine zone and alpine meadows retaining their intact status (Ptaszycka-Jackowska 2005). 1926 saw the first Nature Reserve established on the Czechoslovak side of Mt. Babia Góra (Fig. 3B). In turn, in 1928 forests in the Polish part of the massif's southern slope acquired Protective Forest status, while a stop was put in 1932 to the cutting of dwarf pine on the slope near the tourist hostel near the Babia Góra summit. In 1933 an area of the northern slope of the massif accounting for most of the land between the upper Płaj and the top line of the ridge was set aside as the Babia Góra Nature Reserve extending over an area of 642 ha (Fig. 3A). This reserve with Protective Forests became the nucleus of the National Park on Babia Góra whose founding gained the necessary approval in late 1954 and early 1955. The grazing of oxen on Babia Góra had been banned in 1928 (Jostowa 1986), though until 1954 sheep grazing continued on a small number of clearings, only to disappear altogether in the early years of the National Park's existence (Kostuch 1963). Back in the 1920s, some 400 oxen had grazed the southern slope of the massif above the timberline (in the Polish area) with the four large grazing areas involved later becoming overgrown with dwarf mountain pine scrub (Jostowa 1986).

During World War II (1939-1945), total cutting of forest took place on small areas of the northern slope of Babia Góra. In contrast, in the forests on the southern slope of the massif administered by Slovakia only diseased, broken and fallen trees were used (Dzięciołowski 1963; Fabijanowski \& Gadek 1983). In 1945 the forests of the Polish Academy of Arts and Sciences were incorporated into the State Forests in Zawoja, and the Protective Forests to the Orava Forestry. In the years 1945-1954 only forests in the lower parts of Babia Góra were utilised, which is to say those outside the future National Park (BgPN Archives).

Period VII (after 1954): After the creation of Babiogórski National Park, stand reconstruction commenced with a view to the restoration of the species composition of forests from the period before their exploitation began. Beyond the boundaries of the Park, on the northern foothills of Babia Góra, the felling of spruce monocultures now aged 100 years was continued with. The 1997 enlargement of Babiogórski National Park, from 1704 to $3392 \mathrm{ha}$, resulted in the protection of uneven-aged spruce monocultures in the lower zones of slopes and at the foot of the massif (BgPN Archives). In the Slovak part of Babia Góra, the Nature Reserve of area 118 ha was expanded to 530 ha in 1974 (in the Štátna Prírodná Rezervácia Babia Hora) (Trnka 2005). In the 1960s-1980s, large-scale felling of spruce monocultures was practised at lower altitudes on the slopes of the Slovak part of the massif. Away from the busiest trails, increasing tourist pressure on Babia Góra did not influence the nature of the massif too negatively. However, implementation of proposed ski lifts and ski runs, especially on the slopes formerly degraded by grazing (like the northern slope of Cyl), could lead to even greater activation of avalanches and debris flows, with the result that upper montane forest would be further fragmented (Łajczak et al. 2015).

\section{Scheme for temporal change and spatial differentiation to economic activity}

The duration and spatial extent of the distinguished ways in which Babia Góra and the surroundings have been made economic use of are as shown in Fig. 4. The time scales for the various forms of economic activity in the area have been varied. Exploitation of natural resources started mostly in the valleys surrounding Babia Góra, and was first continued with at the foot of the massif and on the slopes, with a slow but steady move towards the summit ensuing. In some cases highest-intensity economic use of the massif began on slopes of varying altitudes a.s.l. The greatest economic activity on Babia Góra Mt., taking into account all forms of human pressure on the natural environment throughout the altitude profile of the massif, took place in the 19th and early 20th centuries. Mining 
exploration, iron foundries, charcoal production and the transport of timber by water have, for 100 or more years, been historical economic forms of activity in the region. However, grazing on the massif was already almost completely gone more than 50 years ago, albeit continuing in the surroundings in a rudimentary form. Settlements around

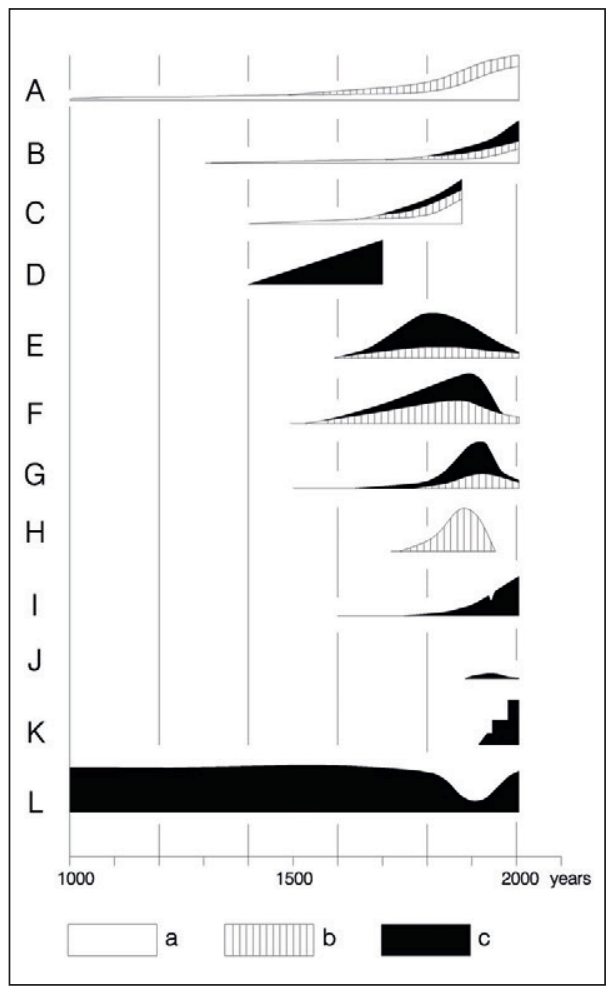

Figure 4. Diagram showing the duration, relative changes in intensity and spatial extents of different economic uses of Babia Góra and its surroundings from the time of onset of permanent settlement

(A-L) - the forms of economic activity referred to in the text. To illustrate changes in the intensity of the different economic uses made of the area in graphic form the same vertical scale was used in each case. Increases in severity are depicted, as are certain cases of a decrease in the impact or even a total disappearance of certain forms of human pressure. The spatial extents (plus altitudes a.s.l.) of different land uses in Babia Góra's: a - surrounding valleys, b - foothills, and $\mathrm{c}$ - slopes
Babia Góra developed, the road network expanded, hiking trails modernised, and a new tourist hostel built in Markowe Szczawiny glade. The number of tourists penetrating the massif in the summer season increased rapidly, though the slightly increased skiing associated with that disappeared in the second half of the 20th century. From the 1920s on the area of Babia Góra Mt. covered by legal protection has been increasing, with reconstruction of spruce monocultures into the mixed forests typical of the lower montane zone. The most visible result of human pressure on Babia Góra was the gradual elimination of forests, and scrub of dwarf mountain pine, with ongoing degradation from the 17th century to the beginning of the 20th century, when there was very major deforestation of the slopes of the massif, as well as unfavourable change in the structure as regards forest species. Since then, forest cover on the massif has increased back close to that existing before the 19th century, with steady improvement of the species composition in forests once used economically. The direction of change was accelerated by die offs of spruce trees increasing for several years as a result of mass outbreaks of bark beetles.

\section{Assessment of anthropogenic changes in the course of the timberline}

From among the economic uses made of $\mathrm{Ba}$ bia Góra, only grazing exerted a direct or indirect influence in the lowering the timberline. Changes in the course of this boundary began at different times and reached different scales in different parts of Babia Góra, the phenomenon being dependent on the time of settlement on the nearby foothill and the accessibility of the slopes. The extent of the grazing-induced degradation of the moreelevated parts of slopes of the massif is indicated by the numerous grazing areas used in the past (Fig. 5). On the southern slope of Babia Góra, oxen and sheep grazing began in the early 17th century, and over the next 300 years took place mainly in the upper part of the upper montane forest zone and in the 


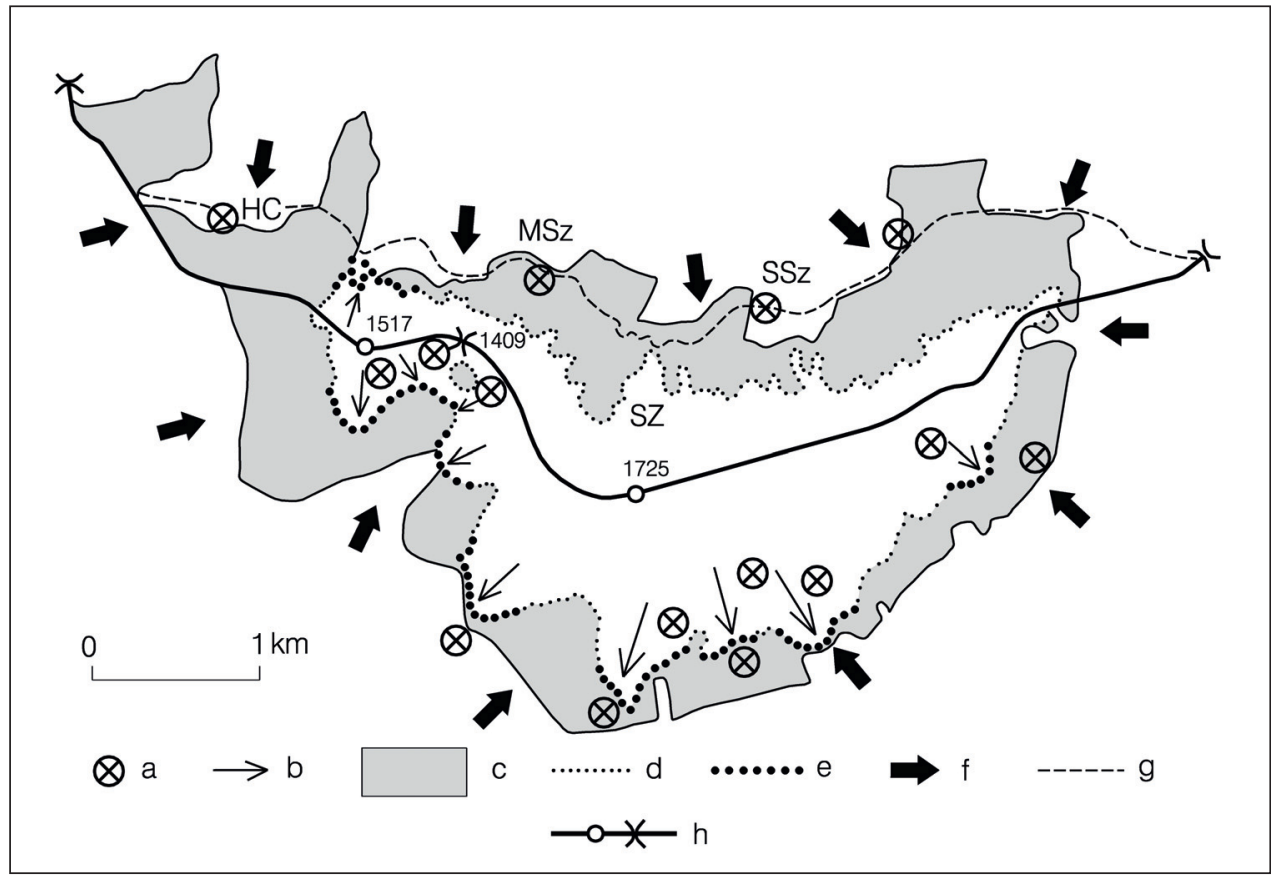

Figure 5. Location of the most extensive areas grazed by oxen and sheep on the slopes of Babia Góra in the vicinity of the timberline and dwarf mountain pine zone, as set against the extent of the fragments of upper and lower montane forest not influenced by large-scale felling in the late 19th and early 20th centuries

$a$ - grazing areas, b - places with a lowered timberline, c - preserved fragments of old-growth forest, $d$ sections of the timberline whose courses were left unchanged by grazing, e - sections of the timberline whose course was lowered in altitude by grazing, $\mathrm{f}$ - direction of deforestation on slopes locally reaching the timberline in the 1920s and 30s, $\mathrm{g}$ - the upper Płaj, $\mathrm{h}$ - the main Babia Góra ridge with the summits of Diablak (1725) and Cyl (1517), the Brona Pass (1409) and the Lipnicka and Jałowiecka Passes. MSz - the Markowe Szczawiny glade, SSz - the Sulowe Szczawiny glade, HC - the Hala Czarnego clearing, SZ - the Szeroki Żleb gully

dwarf pine zone. On the northern slope of the massif the grazing of sheep only took place until the 18th century, over most of the area at a height not exceeding the timberline. Grazing above this boundary only took place in the vicinity of the Cyl summit and the Brona Pass, as well as above the Hala Czarnego clearing.

The direct cause of the local grazinginduced lowering of the timberline on Babia Góra was considered to be the creation of forest clearings located close to the boundary. This situation occurred only on the southern slope of the massif, where the forest belt separating some large clearings from the dwarf pine scrub above it was becoming less compact, to the point where it later disappeared (at the Hustianska, Rabčicka and Kralowa glades). Depending on the size and shape of the clearings, the forest boundary was thus lowered to varying degrees, in the case of the Hustianska clearing by some $200 \mathrm{~m}$ (Zapałowicz 1880).

An indirect cause of the lowering of the timberline and fragmentation of the upper montane forest was reduced compactness of the dwarf pine occurring above it, with complete removal taking place in many areas. Degradation of dwarf pine, especially on the southern slope of Babia Góra, was connected with local cutting of spruce biogroups - and 
despite a ban on this - even the cutting of the uppermost parts of the upper montane forest (Midowicz 1985). In this way, the timberline on Babia Góra was lowered along a long stretch on the steep northern slope of Cyl, where snow avalanches and debris flows became active. The influence of avalanches can also explain the timberline lowering on the southern slope of Cyl, which is the most southern slope of the inclined portion of the entire Babia Góra area. A locally lowered timberline on the rest of the southern slope of the massif should be considered the effect of felling carried out in the past, also in the case of spruce biogroups, which on the steep slopes of headwaters could lead to increased blowing and prolonged retention of snow. In such a situation the hindering of forest regeneration is also due to the activation of avalanches. Despite the regeneration of dwarf mountain pine occurring following the cessation of grazing, the course of the timberline in some parts of the headwater areas on the southern slope of the massif still meanders locally (Czajka \& Kaczka 2014), a feature typical of slopes affected by avalanches. An extensive area of the rugged northern slope of Babia Góra to the east of the Brona Pass was not encompassed by grazing, so the timberline in this part of the massif is, despite again having a meandering course, the result of the action of natural factors only.

Large-scale felling of the upper montane forests on Babia Góra, which entered the upper part of the zone in a few places at the beginning of the twentieth century (Figs. 3 and 5), began to pose a potential threat to the timberline. The real threat only applied to that on the northern slope of Cyl. In this area degradation of the timberline conditioned by grazing began to be intensified by snow avalanches that could reach the deforested part of the slope, causing even-greater fragmentation of what was at that time a narrowed upper montane forest zone (Fig. 3A-right side). On the other hand, on the less-inclined southern slope of Babia Góra, snow avalanches could reach small sizes only in those headwater areas within which large-scale felling of upper montane forest reached the timberline, where they were near the degraded dwarf pine scrub (Fig. 3B). The threat to the timberline on the southern slope of Babia Góra caused by this anthropogenically conditioned factor should be considered minimal, in contrast to that on the northern slope of Cyl.

Within the Babia Góra Massif three areas with varying anthropogenic changes in the course of the timberline were determined:

1. the southern slope,

2. the northern slope in the area of Cyl,

3. the remaining part of the northern slope.

Re 1. - Only on the southern slope of Babia Góra was there a merger of the most extensive forest clearings of the dwarf pine scrub present above it and also encompassed by grazing, which resulted in the creation of extensive grazing areas (or 'halls'). In such places the timberline was lowered markedly (Walas 1933) and this effect was still observable after fifty years (Łuszczyński 1980). The most intensive grazing use of dwarf pine zone and the uppermost clearings on the southern slope of the massif, resulting in the largest local lowering of the timberline, should be dated to the late 19th and early 20th centuries. It could be confirmed in the 1960s, despite the passage of nearly 40 years after the cessation of grazing, with the extent of the Hustianska, Rabčicka and Kralowa clearings on the southern slope of Babia Góra determining the marked lowering of the timberline in these places (Czajka \& Kaczka 2014), in relation to the extent of the clearings recorded in the 1870s (Zapałowicz 1880). Following the removal of grazing the degraded timberline was progressive in nature along long stretches (Czajka \& Kaczka 2014).

Re 2. - On the northern slope of Babia Góra it was only in the western part that grazing of sheep took place well outside the original clearing (i.e. Hala Czarnego), and covered a large part of the slope and the summit of $\mathrm{Cyl}$ and the Brona Pass covered with upper montane forest and dwarf pine (BgPN Archives) (Fig. 6A). Due to the state border demarcated along the main ridge, sheep grazing could not be carried out on the southern side (Fig. 6B). 
A

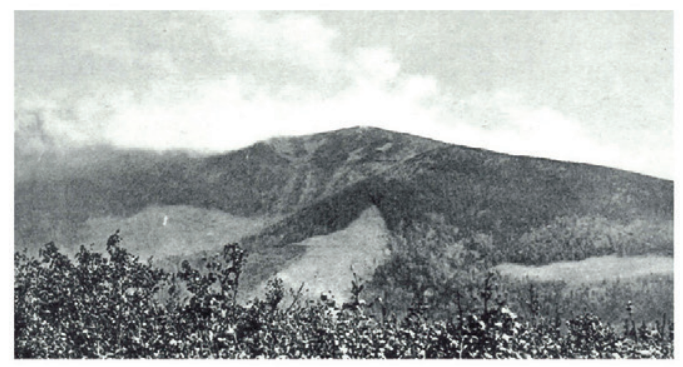

(HC) a $\quad-\mathrm{O} \rightarrow \mathrm{H}$

\section{B}

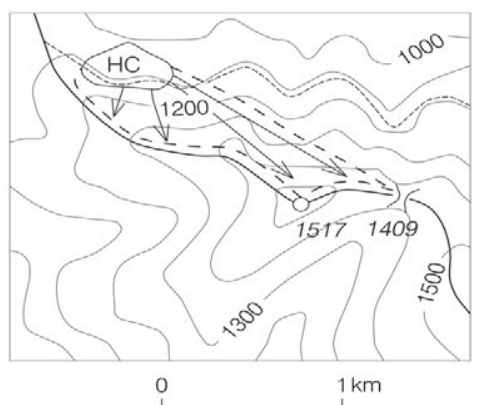

Figure 6. A - the northern slope of Cyl (to $1517 \mathrm{~m}$ a.s.l.) encompassed by sheep-grazing as of 1930 . On the right, the clearing of Hala Czarnego. Extensive deforestation of the slope taking place in the late 19th and early 20th centuries. Fragmentation of forest visible at the peak of Cyl. Inside on the left the peak of Babia Góra proper (at 1725 m a.s.l.) shrouded in cloud, B - the extent of sheep-grazing on the northern slope of Cyl. a - limits of the grazed Hala Czarnego clearing, the centre of grazing in the area, $b$ - the extent of grazing in the altitudinal zones supporting upper montane forest and dwarf mountain pine, $\mathrm{c}$ - the main ridge of the massif with the Cyl summit and Brona Pass (to $1409 \mathrm{~m}$ a.s.l.) along which the state border is delineated, $d$ - the upper Płaj

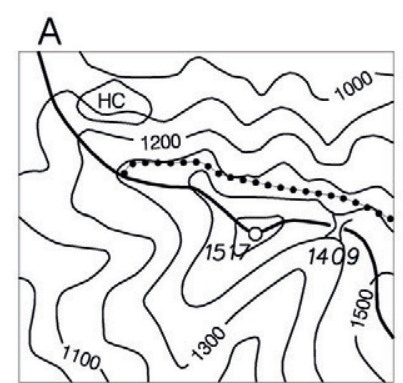

D

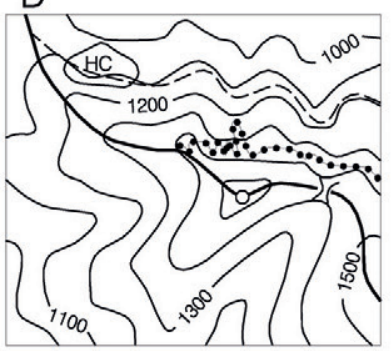

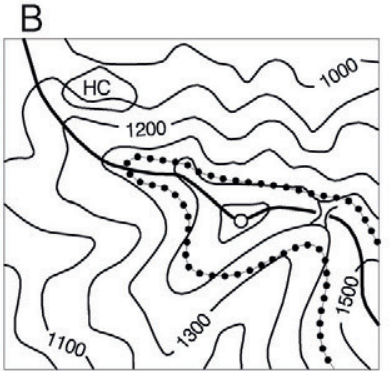

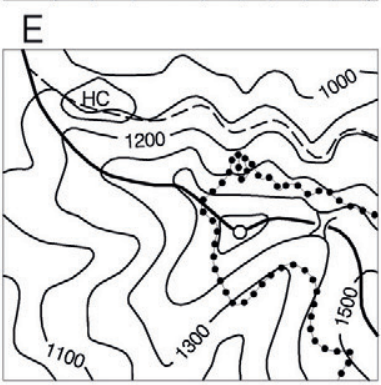

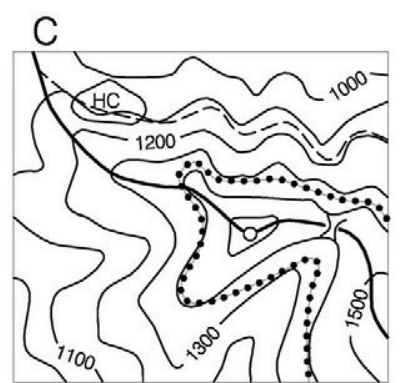

$1 \mathrm{~km}$

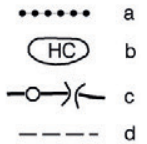

Figure 7. The course of the timberline surrounded by the summit of Cyl (at $1517 \mathrm{~m}$ a.s.l.) after: $\mathrm{A}$ - the map by Liesganig et al. (1790) - northern slope only, B - Zapałowicz (1880), C - Walas (1933), D - Kasprowicz (1980) - northern slope only, E - current status. a - the timberline, b - the Hala Czarnego clearing, in case E overgrown with forest, $\mathrm{c}$ - the main ridge of the massif with the Cyl summit and Brona Pass (at 1409 m a.s.l.), $d$ - the upper Płaj (in the cases of A and B there was no path in existence) 
However, the map by Liesganig et al. (1790) show the timberline reaching beyond the present-day level to the west of the Cyl summit, which means a lower position at the turn of the 18th and 19th centuries (Fig. 7A). Also the map from the work by Zapałowicz (1880), already prepared on the isohypse drawing, shows the timberline as lower than at present on the main ridge of the massif on the west side of this summit (Fig. 7B). On the southern slope of Cyl, the timberline was then close to where it is at present, and on the northern slope the forest reached to an altitude of about $1400 \mathrm{~m}$ a.s.I. Then the center of grazing on the Cyl ridge was the area on the southern side of the Brona Pass, where dwarf pine scrub was cut away completely and the timberline was lowered (see Fig. 5). The extensive areas grazed and covered with grass on this part of Babia Góra are indicated by the quote given earlier from the paper by Zejszner (1848). On the other hand, on the map in the paper by Walas (1933), the course of the timberline in the end-stage of grazing on Babia Góra was recorded. This map shows the lowered (to a level of 1300-1350 m a.s.l.) timberline on the northern slope of Cyl, as well as its more-elevated course on the main ridge on the west side of this summit (about $1400 \mathrm{~m}$ a.s.l.). On the southern slope of Cyl there were no significant changes in the course of the timberline (Fig. 7C).

Progression of the timberline on the west side of Cyl was probably initiated by the rules introduced at the beginning of the 1920s of the twentieth century, on the then determined Polish-Czechoslovakian border, which prevented grazing from taking place in the border zone. This resulted in increased intensity of grazing on the slopes of Cyl on both sides of the state border, and thus in a lowering of the timberline, especially on the northern slope. The upper montane forest on the northern slope of Cyl was then fragmented by avalanche tracks, which interrupted the continuity of the forest in several places (see Figs. 3A and 6A). The forest degradation conditioned by grazing on this slope had to start early, as its advanced stage by the middle of the 19th century is made clear by the debris flows marked on the Eljasz-Radzikowski watercolour in summer 1860 (Ptaszycka-Jackowska 2005: 150), which crossed the timberline. The great activity of geomorphological processes modelling the degraded slope is confirmed by the note in the paper by Zapałowicz (1880:167): "On the north side [on the northern slope of Babia Góra dwarf pine] goes into the forest in two locations in narrow branches: at the Sokolica foot (...) to 1240 [m a.s.I.], while at the Markowy Potok stream to 1190 [m a.s.I.], forming here (...) an oasis in the woods. At the stream it occurs in the scrub already at an altitude of 1145 [m a.s.l.]". The lowest-situated location for this species on Babia Góra can only be explained by a high intensity of debris flows that could move the dwarf pine on the northern slope of Cyl. Walas (1933) did not confirm the presence of dwarf pine in this part of Babia Góra, which may indicate a reduction in the severity of debris flows in the previous 50 years, leading to the disappearance of isolated low-lying localities for the species. In later years not even single specimens of dwarf mountain pine were to be found in this area.

At the beginning of the twentieth century the zone on the northern slope of Cyl covered by upper montane forest was narrowed to 50 meters - from the top of the slope, as a result of grazing, and from the bottom of the slope by the large-scale felling of forest. This allowed for the expansion of avalanche tracks, whose range even greater for a time, despite the removal of grazing from the slope and the afforestation of the previously-deforested part of it, as documented on the map in the work by Kasprowicz (1980) - (Fig. 7D), as compared with the current course of the timberline in the area (Czajka \& Kaczka 2014) -(Fig. 7E). Despite the activation of avalanches on the northern slope of Cyl, a stabilization resulting in the fossilization of debris flows took place. In this respect, the changes in the course of the timberline on the northern slope of the relevant section of Babia Góra are fundamentally different from those on the remainder of the massif. During the last 50 years the timberline on the northern slope of Cyl has changed 
little, with most of the area at altitudes ranging from 1200 to $1400 \mathrm{~m}$ a.s.l., though lowered to $1106 \mathrm{~m}$ a.s.l. at the longest avalanche track (Hudziak 1987; Czajka \& Kaczka 2014).

Re 3. - The rest of Babia Góra's northern slope was not found to be displaying anthropogenically-conditioned changes in the course of the timberline, as the steep part of this slope was not encompassed by grazing activity, and an upper range of large-scale felling of forest in only a small area in the vicinity of the Sulowe Szczawiny clearing led to extensive narrowing in the upper montane forest (Figs. 3A and 5). Local avalanche-induced lowering of the course of the timberline in the vicinity of this clearing did not result in the fragmentation of the upper montane forest.

\section{Discussion of results and conclusions}

Over the last 600 years, the Babia Góra Massif and its surroundings have been subject to the same economic uses as the neighbouring massif of the Tatra Mountains (Midriak 1994; Mirek 1996; Boltižiar 2007) and Mt. Pilsko (Łajczak 2004a, 2005, 2011, 2012), as well as other high-mountain ranges in the Carpathians (Midriak 1994; Weisberg et al. 2013), the Karkonosze Mts (Jahn 1985) and the Alps (Motta \& Nola 2001). Like those in these other mountain ranges, change in the natural environment on Babia Góra was most pronounced under the influence of grazing, as well as forest management related to the production of charcoal. That said, the intensification of agriculture on the Babia Góra Massif proper was a limited affair, while small-scale mining and metallurgy developments taking place in nearby valleys achieved minimum historical intensity when compared with those in other mountain areas (Jahn 1985; Mirek 1996; Holtmeier 2009; Slaymaker \& Embleton-Hamann 2009). There is no information regarding the occurrence on Babia Góra of on any of the forest fires shown to have caused large-scale temporary loss of forest cover in other mountainous areas (Holtmeier 2009). Nor is there any evidence that deforestation through the deliberate use of fire on forest slopes has ever been carried out on Babia Góra.

The Massif under study also differs from other high-mountain areas in the timing of various forms of human pressure. Most economic uses of the massif were initiated later here than in other ranges, while some forms of human activity have already been consigned to history. For example, the period of rapacious forest management here was of only 90 years' duration, while the associated trace mining and metallurgy, only ever developed to a limited extent, had already disappeared by about 130 years ago. In contrast to that in neighbouring mountain areas, the local foothills development of health facilities, accommodation and road networks was always more limited. Noting the severe environmental degradation of other mountain ranges thanks to the presence of many developments of these types (Jahn 1985; Holtmeier 2009; Slaymaker \& Embleton-Hamann 2009), underinvestment in the tourist base around Babia Góra can be thought to have protected the mountain against more-severe degradation of nature caused by tourism (Łajczak et al. 2015). The lack of ski facilities was also 'helpful', these having caused major changes in the landscape on the slopes of Pilsko and in the Tatras (Mirek 1996; Łajczak 2004a, 2005, 2011, 2012).

One of the most visible effects of the economic use made of Babia Góra's natural resources is the lowering of the timberline. This has affected most of the gently-sloping southern side of the massif, though only a single part of the steep northern slope. As is implied, this asymmetry in the degree of degradation of the timberline has not reflected differences in climatic conditions between the southern and northern slopes, but rather the greater accessibility of the less-inclined southern slope. Among the many possible anthropogenic reasons for a lowering of the timberline (Holtmeier 2009), grazing is the only one needing to be invoked in the case of Babia Góra, as this process is indeed seen to have developed on the massif's southern slope at the beginning of the 17th century, while only beginning 
on the northern slope in the 18th. The activity had in turn ceased in both areas by the middle of the 20th century. A direct impact of grazing manifested in a lowering of the timberline by up to $200 \mathrm{~m}$ in areas of high-altitude forest clearing is only to be made out on the southern slope. Local activation of short avalanches as a reflection of the degradation of the scrub of dwarf mountain pine was a further indirect result of grazing on the same slope. A more serious grazing-related degradation of the timberline due to the past activation of long avalanches and debris flows can only be implied for one part of the steep northern slope of Babia Góra.

The establishment of Nature Reserves here in 1926 and 1933, and especially of the National Park in 1955, resulted in the removal of grazing from Babia Góra, which in turn allowed for the regeneration of dwarf mountain pine - as a prerequisite for the return of a timberline depending solely on climatic,

\section{References}

BGPN ARCHIVES. Archival materials of the Babiogórski National Park, Zawoja.

BoltıžIAR M., 2007. Štruktúra vysokohorskej krajiny Tatier (vel'komierkové mapovanie, analýza a hodnotenie zmien aplikáciou údajov dial'kového prieskumu Zeme). Nitra: Fakulta prírodných vied Univerzity Konštantína Filozofa, Ústav krajinnej ekológie SAV Bratislava, pobočka Nitra, Slovenský národný komitét preprogram UNESCO Človek a biosféra.

BRODA J., 1963. Historia osadnictwa w regionie babiogórsko-pilszczańskim [in:] W. Szafer (ed.), Babiogórski Park Narodowy, Kraków: Wydawnictwo Zakładu Ochrony Przyrody PAN, pp. 225-233.

Chmielowski B., 1745-1756. Nowe Ateny albo Akademia Wszelkiey Scyencyi Pełna. Part 2, Lwów: Drukarnia Pawła Józefa Golczewskiego.

CZAJKa B., KaCZKa R.J. 2014. Dendrochronologiczna charakterystyka górnej granicy lasu na Babiej Górze w strefie jej progresu. Studia i Materiały Centrum Edukacji Przyrodniczo-Leśnej, vol. 3, no. 16 , pp. 42-52. orographic and edaphic factors, as well as the severity of slope processes. Nevertheless, after 60 years, the process in the area embraced by so-called 'strict protection' has not yet been completed, even though its course is not interfered with by increased summerseason tourist traffic.

\section{Acknowledgements}

The paper has been written within the framework of science project MNiSW N N306 070640 entitled Natural and anthropogenic conditioning of the occurrence of the upper timberline on Babia Góra Mountain, and its dynamics over the last 200 years.

Editors' note:

Unless otherwise stated, the sources of tables and figures are the authors' on the basis of their own research.

DE LIPSZKY J., 1806. Mappa Generalis Regni Hungariae partiumque adnexarum Croatiae, Slavoniae et Confiniorum Militarium Magni item Principatus Transylvaniae Mappa Generalis Regni Hungariae. Pesthini.

DŁugosz J., 1468. Chronographia Regni Poloniae.

DROBISZ Z., 1985. Kopalnictwo rud żelaza dla Huty Węierska Górka. Karta Groni, 13, Żywiec: Towarzystwo Miłośników Ziemi Żywieckiej.

DuŃCZEWSKI S., 1755-1769. Kalendarze. Zamość.

Dzı̨̨CIOŁOWskı R., 1963.Z historii gospodarki leśnej na Babiej Górze [in:] W. Szafer (ed.), Babiogórski Park Narodowy, Kraków: Wydawnictwo Zakładu Ochrony Przyrody PAN, No. 22, pp. 235-241.

FABIANOWSKI J., GĄDEK K., 1983. Lasy Babiogórskiego Parku Narodowego [in:] W. Szafer (ed.), Babiogórski Park Narodowy, Kraków: Wydawnictwo Zakładu Ochrony Przyrody PAN, pp. 179-196.

HAUR J.K., 1660. O górach wielkich wyniosłych. Kraków.

HolekSA J., Szwagrzyk J., 2005. Szata roślinna [in:] D. Ptaszycka-Jackowska (ed.), Światy Babiej Góry. Zawoja: Babiogórski Park Narodowy, pp. 43-93. 
Holtimeier F.K., 2009. Mountain timberlines: Ecology, patchiness and dynamics. Advances in Global Change Research, 36, Dordrecht: Springer.

HrosieńSKI M., 1637. Opisanie ciekawe gór Tatrów. Kraków.

HudzIAK E., 1987. Lawiny śnieżne na Babiej Górze [in:] J. Pawłowski (ed.), Prace Babiogórskie, vol. 7. Kraków: Ośrodek Kultury Turystyki Górskiej Polskiego Towarzystwa Turystyczno-Krajoznawczego na Babiej Górze, pp. 96-98.

JAHN A. (ed.), 1985. Karkonosze polskie. Wrocław: Zakład Narodowy im. Ossolińskich.

JANICKI Z., 1996. Historia Zawoi do końca XIX w. [in:] U. Janicka-Krzywda (ed.), Monografia Zawoi. Kraków-Zawoja: Forma, pp. 35-60.

Jost H., 2004. Dzieje górnictwa i hutnictwa w Tatrach Polskich. Zakopane: Towarzystwo Muzeum Tatrzańskiego.

Jostowa W., 1983. Pasterstwo na południowych stokach Babiej Góry (w granicach Polski) [in:] J.M. Stroka (ed.), Gdy do tej Babiej Góry przyjdziesz, part 1, Bielsko-Biała: Zarząd Wojewódzki Polskiego Towarzystwa Turystyczno-Krajoznawczego, pp. 105-111.

Jostowa W., 1986. Z historii osadnictwa Polskiej Orawy [in:] :] J.M. Stroka (ed.), Gdy do tej Babiej Góry przyjdziesz, part 2, Bielsko-Biała: Zarząd Wojewódzki Polskiego Towarzystwa Turystyczno-Krajoznawczego, pp. 199-211.

Kasprowicz M., 1980. Górna granica lasu na pótnocno-zachodnich zboczach Babiej Góry. Zawoja: BgPN [MA thesis].

KAWECKI W., 1936. Lasy Żywiecczyzny a pasterstwo. Sylwan, vol. 54, no. 2, ser. B, pp. 49-55.

KAWECKI W., 1939. Lasy Żywiecczyzny, ich teraźniejszość i przeszłość. Kraków: Polska Akademia Umiejętności.

KMI, 1915. Spezialkarte der Österreichisch-Ungarischen Monarchie: Zone 13, Kol. XXXIV: Hliboka. Map at a scale of 1:75,000. Vienna: Kaiserlich-Königliches Militär Geographisches Institute.

KostuCH R., 1963. Gospodarka rolna i pasterstwo regionu babiogórskiego [in:] W. Szafer (ed.), Babiogórski Park Narodowy, Kraków: Wydawnictwo Zakładu Ochrony Przyrody PAN, No. 22, pp. 243-256.

Kummerer Ritter von Kummersberg C. (ed.), 1855. Administrative-Karte von den Königreichen Galizien und Lodomerien mit dem Grossherzogthume Krakau und den Herzogthümern
Auschwitz, Zator und Bukowina: In 60 Blättern. Map at a scale of 1:115,000, Vienna: Artaria.

Kuriakova E., Arcikiewicz A., Grzybacz K., 2007. Drogi i bezdroża Orawy. Wadowice - Zubrzyca Górna: Oficyna Wydawnicza Grafikon, Stowarzyszenie Przyjaciół Babiej Góry.

LesZCZYCKI S., 1939. Z geografii uzdrowisk Polski. Turyzm Polski, vol. 2, no. 5, pp. 96-102.

Liesganig J., Liechtenstern von J., Prixner G. (eds.), 1790. Regna Galiciae et Lodomeria. Map at a scale of 1:288,000, Vienna. Second edition in 1824.

ŁADOWSKI R., 1783. Historya naturalna Królestwa Polskiego. Kraków.

ŁAJCZAK A., 1995. Matka niepogód [in:] U. Janicka-Krzywda, A. Łajczak, Babiogórskie ścieżki, Poznań: Colgraf-Press, pp. 97-224.

ŁAJCZAK A., 2004a. Etapy kształtowania się krajobrazu kulturowego gór w układzie wysokościowym, na przykładzie masywu Pilska w Beskidzie Żywieckim [in:] U. Myga-Piątek (ed.), Przemiany krajobrazu kulturowego Karpat: Wybrane aspekty, Prace Komisji Krajobrazu Kulturowego, 3, pp. 11-32.

ŁaJCZAK A., 2004b. Wody Babiej Góry [in:] B.W. Wołoszyn, A. Jaworski, J. Szwagrzyk (eds.), Babiogórski Park Narodowy. Monografia przyrodnicza, Kraków: Wydawnictwo i Drukarnia Towarzystwa Słowaków w Polsce, pp. 153-177.

ŁAJCZAK A., 2005. Antropopresja w górach - rozwój w czasie i zróżnicowanie w układzie wysokościowym, na przykładzie masywu Pilska w Beskidach Zachodnich [in:] A. Łajczak (ed.), Materiały Warsztatów Geomorfologicznych - Antropopresja w środowisku górskim - zapis zmian w formach terenu i osadach, Korbelów-Pilsko (Beskid Żywiecki), 27-30 maja 2005 r., Sosnowiec: Wydawnictwo Wydziału Nauk o Ziemi. Uniwersytet Ślq̨ski, pp. 11-30.

ŁAJCZAK A., 2011. Masyw Pilska w Beskidzie Żywieckim. Przyroda i człowiek. Kraków: Instytut Botaniczny im. W. Szafera PAN.

ŁAJCZAK A., 2012. Ocena antropogenicznych zmian w rzeźbie masywu Pilska i sqsiadujacego obszaru [in:] A. Łajczak (ed.), Antropopresja w wybranych strefach morfoklimatycznych: Zapis zmian w rzeźbie i osadach. Sosnowiec: Wydawnictwo Wydziału Nauk o Ziemi. Uniwersytet Ślaski, pp. 242-253. 
Łauczak A., CZAuka B., KaczKa J.R., 2014, The new features of landslide relief discovered using LiDAR - case study from Babia Góra massif, Western Carpathian Mountains. Quaestiones Geographicae, vol. 33, no. 3, pp. 77-88.

ŁAJCZAK A., CZAJKA B., KACZKA J.R., 2015. Development of touristic infrastructure at Babia Góra Mt. (Western Carpathians) in conditions of intensive slope processes hazard. Prace Geografczne. Uniwersytet Jagielloński Instytut Geografii i Gospodarki Przestrzennej, 136 (in print).

ŁUBIEŃSKI W., 1741. Świat we wszystkich swoich częściach. Kielce.

ŁUSZCZYŃSKI J., 1980. Górna granica lasu na południowo-wschodnich zboczach Babiej Góry. Zawoja: BgPN Archive [MA thesis].

Marcin of Urzęoów, 1595. Herbarz Polski to jest o przyrodzeniu ziót $i$ drzew rozmaitych $i$ innych rzeczy do leczenia należnych. Kraków.

MAZUREK P., 2008. Zapory piętrzace na potokach beskidzkich używanych w przeszłości do spławu drewna. Sosnowiec: Wydział Nauk o Ziemi. Uniwersytet Śląski [MA thesis].

MerkAtor G. (ed.), 1585. Polonia et Silesia. Duisburg: Gerard Mercator.

Midowicz W., 1930. Babia Góra: Monografja turystyczna. Vol. 1, Żywiec: Wydawnictwa Oddziału Babiogórskiego Polskiego Towarzystwa Tatrzańskiego, pp. 1-47.

Mıdowicz W., 1974. Babia Góra [in:] A. Łączyński (ed.), Karpaty, vol. 2, Kraków: Oddział Krakowski Polskiego Towarzystwa Turystyczno-Krajoznawczego, pp. 61-96.

Midowicz W., 1985. Z historii niszczenia przyrody babiogórskiej [in:] T. Nowalnicki (ed.), Prace Babiogórskie, vol. 6. Kraków: Ośrodek Kultury Turystyki Górskiej Polskiego Towarzystwa Turystyczno-Krajoznawczego na Babiej Górze, pp. 41-45.

Midowicz W. (ed.), 1992. Mała Encyklopedia Babiogórska. Pruszków: Oficyna Wydawnicza Rewasz.

MIDRIAK R., 1994. Geoekólogia vysokých pohori Slovenska. Zvolen: Technická univerzita, Edične stredisko-TU.

MiEg VON F. (ed.), 1779-1782. Karte des Königreiches Galizien und Lodomerien. Map at a scale of $1: 28,800$, Vienna.

Mirek Z., 1996. Antropogeniczne zagrożenia i przekształcenia środowiska przyrodniczego [in:] Z. Mirek (ed.), Przyroda Tatrzańskiego Parku
Narodowego, Zakopane: Wydawnictwo Tatrzańskiego Parku Narodowego, pp. 595-617.

Motta R., Nola P., 2001. Growth trends and dynamics in sub-alpine forest stands in the Varaita Valley (Piedmont, Italy) and their relationship with human activities and global change. Journal of Vegetation Science, vol. 12, no. 2, pp. 219-230.

NowalnICKI T., 1979. Poznanie Babiej Góry do początków XX w. [in:] T. Nowalnicki (ed.), Prace Babiogórskie, vol. 1. Kraków: Ośrodek Kultury Turystyki Górskiej Polskiego Towarzystwa Turystyczno-Krajoznawczego na Babiej Górze, pp. 26-41.

NowalnICKI T., 1980. Stawek pod Kłodq - Morskie Oko [in:] T. Nowalnicki (ed.), Prace Babiogórskie, vol. 2. Kraków: Ośrodek Kultury Turystyki Górskiej Polskiego Towarzystwa Turystyczno-Krajoznawczego na Babiej Górze, pp. 92-95.

NowALNICKI T., 1982. Znaki poszukiwaczy skarbów na Kamionku (913,6 m) [in:] T. Nowalnicki (ed.), Prace Babiogórskie, vol. 4. Kraków: Ośrodek Kultury Turystyki Górskiej Polskiego Towarzystwa Turystyczno-Krajoznawczego na Babiej Górze, pp. 9-11.

NowAlnICKI T., ŁAJCZAK A., 1981. Złota Studnia [in:] T. Nowalnicki (ed.), Prace Babiogórskie, vol. 3. Kraków: Ośrodek Kultury Turystyki Górskiej Polskiego Towarzystwa Turystyczno-Krajoznawczego na Babiej Górze, pp. 15-18.

Orteliusz A., 1573. Teatrum orbis terrarium. Antverpiae: Christophorum Plantinum.

PALENIK J., 1980. Mineralne źródła orawskich podnóży Babiej Góry [in:] T. Nowalnicki (ed.), Prace Babiogórskie, vol. 2. Kraków: Ośrodek Kultury Turystyki Górskiej Polskiego Towarzystwa Turystyczno-Krajoznawczego na Babiej Górze, pp. 18-20.

PIASECKI W., 1999. Charakterstyka fitosocjologiczna subalpejskich zarośli kosodrzewiny Pinus mugo Turra na Babiej Górze. Kraków: Wydział Leśny. Uniwersytet Rolniczy [MA thesis].

PolaK K., 1980. Fragment dotyczqcy Babiej Góry z opisem Ziem Monarchii Austriackiej z roku 1843 - wybór i tłumaczenie [in:] T. Nowalnicki (ed.), Prace Babiogórskie, vol. 2. Kraków: Ośrodek Kultury Turystyki Górskiej Polskiego Towarzystwa Turystyczno-Krajoznawczego na Babiej Górze, pp. 26-26.

PoręBSKI S. (ed.), 1563. Ducatus Oswieczensis et Zatoriensis descriptio. Antverpiae: Christophorum Plantinum. 
PtASZYCKA-JACKOWSKA D. (ed.), 2005. Światy Babiej Góry. Zawoja: Babiogórski Park Narodowy.

RalSKI E., 1931. Łaki, polany i hale Pasma Babiej Góry. Kraków: Nakładem Polskiej Akademii Umiejętności.

Rizzi Zannoni J.A.B., 1772. Carte de la Pologne divisée par provinces et palatinats et subdivisée par districts construite par. Map at a scale of $1: 692,000$. Paris.

Rucińskı H., 1976. Najdawniejsza mapa Górnej Orawy jako przyczynek do dziejów osadnictwa. Wierchy, 45, pp. 148-148.

Rydlewski J., Valde-Nowak P., 1984.Z najdawniejszej przeszłości Orawy. Wierchy, 51, pp. 7-25.

RzĄCZYŃski G., 1721. Historia Naturalis Curiosa Regni Poloniae. Part I, Sandomierz.

RzĄCYYŃski G., 1742. Historia Naturalis Curiosa Regni Poloniae. Part II, Sandomierz.

SChneider A., 1871. Encyklopedya do krajoznawstwa Galicyi pod względem historycznym, statystycznym, topograficznym, orograficznym, hydrograficznym, geognostycznym. Vol. 2, Lwów.

Siemionow A., 1983. Od Nigra Silva do Rezerwatu Biosfery UNESCO [in:] J.M. Stroka (ed.), Gdy do tej Babiej Góry przyjdziesz, part 1, Bielsko-Biała: Zarząd Wojewódzki Polskiego Towarzystwa Turystyczno-Krajoznawczego, pp. 87-103.

Slaymaker O., Embleton-Hamann C., 2009. Mountains [in:] O. Slaymaker, T. Spencer, C. EmbletonHamann (eds.), Geomorphology and global environmental changes, Cambridge: Cambridge University Press, pp. 37-70.

Sosnowski K. 1923. Babia Góra. Wierchy, 1, pp. 57-57.
Staszic S., 1815. O ziemiorodztwie Karpatow $\mathrm{i}$ innych gor i rownin Polski. Warszawa: Drukarnia Rzadowa.

Stieber Z., 1924. Ślady po dawnych pracach górniczych na grzbietach górskich w Beskidach Zachodnich. Wierchy, 2, pp. 254-255.

SYREŃSKI S., 1613. Zielnik herbarzem z języka łacińskiego zowiq. Kraków.

TRNKA R., 2005. Przyroda słowackiej części Babiej Góry [in:] D. Ptaszycka-Jackowska (ed.), 2005. Światy Babiej Góry. Zawoja: Babiogórski Park Narodowy, pp. 123-143.

Walas J., 1933. Roślinność Babiej Góry. Warszawa: Państwowa Rada Ochrony Przyrody.

Weisberg P.J., Shandra O., Becker M.E., 2013. Landscape influences on recent timberline shifts in the Carpathian Mountains: Abiotic influences modulate effects of land-use change. Arctic, Antarctic and Alpine Research, vol. 45, no. 3, pp. 404-414.

Wieser T., Pelczar A., Gucwa I., Mildner Z., SZCZUROWSKA J., 1959-1960. Charakterystyka petrograficzna skat serii magurskiej z obszaru Babiogórskiego Parku Narodowego. Zawoja: Babiogórski National Park Archives.

WyrozumskA B., 1977. Drogi w Ziemi Krakowskiej do końca XVI w. Prace Komisji Nauk Historycznych PAN, 43, Wrocław: Zakład Narodowy im. Ossolińskich.

Zapałowicz H., 1880. Roślinność Babiej Góry pod względem geograficzno-botanicznym. Sprawozdania Komisji Fizjograficznej Akademii Umiejętności, 14, Kraków: Akademia Umiejętności.

ZejSzNer L. 1848. Podróże po Beskidach, czyli opisanie części gór Karpackich, zawartych pomiędzy źródłami Wisty i Sanu. 